Vol 2 No 1, November 1995

\title{
INVESTIGATIVE JOURNALISM IN MELANESIA: IS IT NEEDED?
}

Some argue there is no place for investigative journalism in Melanesia, particularly in Papua New Guinea. Such critics believe that for investigations to be effective then politicians must make changes. A media panel at a UNESCO-funded seminar at the University of PNG debates these issues.

\section{By WALTER NALANGU}

HELLO AND WELCOME to this documentary program. I'm Walter Nalangu and in this program we'll mainly be looking at a Certificate in Investigative Journalism course just introduced by the South Pacific Center for Communication and Information in Development (SPCenCIID) at the University of Papua New Guinea. Investigative journalism -- is it needed in our society?

For the first time ever, within the Pacific Islands region, a full tertiary course on Investigative Journalism has been introduced. SPCenCIID introduced this 16-week course at UPNG's Waigani Campus in the second semester of this year.

Not many, if any at all, of the practising journalists -- especially in Melanesia -- have attended formal courses on investigative journalism. Similarly, few journalists and the public within the region have some basic ideas of what investigative journalism actually is. University of Papua New Guinea lecturer in journalism David Robie, who is coordinator of the course, explains what is involved:

DAVID ROBIE: The term 'investigative reporting' is often misleading. In a sense, any good reporting should be 'investigative'. It is a question of degree. In the public eye, and among many journalists, investigative journalism is only thought of in terms of an expos at the expense of the subjects of the investigation. In fact, investigative reporting can be much broader in scope and can also include interpretative and in-depth reporting, or evaluative feature writing.

However, according to Mr Robie, much of what we call investigative journalism or reporting differs in important ways from routine reporting. These differences usually include the idea that the investigation will trigger some action. 
ROBIE: Investigative reporting usually involves a longer time frame to research and write than other forms of reporting. An investigative report usually requires more resources in staff, time and money. And then the investigative report usually involves some risks, threats or legal obstacles that could be involved in the research and publication or broadcast.

Another factor is that mostly experienced journalists are involved, and usually a high level editorial decision is taken over whether to investigate the story and publish or broadcast. Certainly it is vital for reporters to realise that they shouldn't attempt controversial investigations without the sanction and support of their news organisations.

Investigative journalism runs in Mr Robie's family. His great-great grandfather, James Robie, was the owner-editor of a famous Scottish newspaper, The Caledonian Mercury, and was presented with an award by the grateful citizens of New York for his role as a 'muckraker', or investigator, of his day.

If one ever gets down to tackling investigative journalism, it really is quite difficult. One of Australia's leading investigative journalists, Wendy Bacon, now an associate professor who has been resource person for the investigative journalism course, confirms that the difficulty exists. The basis of investigative journalism or a major reason why some reporters try to be investigative journalists is because of a belief in the public's right to know the truth.

WENDY BACON: Governments have massive -- perhaps not massive in Pacific countries -but certainly governments have plenty of PR people and so do big corporations. They put out lots of information but all too often that information leaves big gaps and doesn't really explain very much. In some countries it actually amounts to lies.

So people think of investigative journalism as exposing. But often, really, all an investigative journalist is trying to do is just put things together, just to tell a story to people about what is actually happening to them.

And so I think that's what the bottom line is. Why we try to do investigative journalism is so that the public actually know what the story is -- at least as far as we're able to find out.

And from experience, Professor Wendy Bacon says it is likely that the attitude of governments and big companies towards investigative journalists may not be very positive.

BACON: I don't think governments anywhere like investigative journalism. They like to control the flow of information and that's not in any one particular part of the world. Some governments can tolerate it more than others, but I don't think there's ever been a government that likes, really embraces, investigative journalism, nor do big companies because their bottom line is just making sure that the information creates an environment where they can continue to make as much money as possible. 
So obviously they're not going to like investigative journalism either. And for that reason, if you approach it from their point of view, their job is to make life difficult for investigative journalists, and I think they certainly managed to do that in many cases.

Associate Professor Bacon has been renowned for exposing corrupt activities of senior New South Wales police officers. She was also involved in exposing foreigners implicated in the 1987 military coups in Fiji. She reaffirms that investigative journalism involves legal and official obstacles -- the way the law can frustrate what journalists want to do. Also the legal obligations and difficulties confronting reporters when working as investigative journalists.

BACON: Often the most difficult thing for investigative journalists is that most journalists don't do investigative journalism. So that sometimes the people who are actually your biggest problem are the people who are prepared to be the outlets for the Government and company public relations.

And if you look in newspapers anywhere, I would say that most of what appears in the newspaper is actually just regurgitating what people have said to journalists and what powerful people have said to journalists.

Now I think that it is part of the role of journalism to actually report what people in official places say, but all too often it's reported without asking more questions. That's not to say that there's not a very strong group who do ask probing questions.

There's almost an international, I think, group of journalists that in our region have given each other support and continue to do so, so that we can continue to do investigative journalism. And I think without that sort of support network existing, it's going to be difficult for people in any one place to keep going.

Associate Professor Wendy Bacon is currently director of the Australian Center for Independent Journalism at the Sydney University of Technology, Australia.

Does the difficulties involved mean that investigative journalism should not be practised in Melanesia, let alone Papua New Guinea? Not at all. Many people in Melanesian society of today have expressed support, saying that investigative journalism is vital. One of the people who publicly supports investigative journalism in Melanesia is an elder statesman of Papua New Guinea, Sir Paulias Matane.

SIR PAULIAS MATANE: It is really needed in Papua New Guinea at this time. I was very much interested in the front page report of last's Saturday Independent on one of our socalled national leaders. You know the rest of the story -- but that was a good piece of work.

As I see investigative journalism, it is tough, and we should not concentrate only on corruption. We should look at other things as well -- politics, economy, social issues, the whole range of things. And as I see today, the journalists -- you people here -- are the saviours of Papua New Guinea, and I'll tell you why I say this. 
The Government has decided to abolish the Department of Information and Communication. They have not even funded the National Broadcasting Corporation properly. Some of their stations are not working and I don't think they take reporting as a very important issue. I really don't think so.

So these issues are very serious. That's why I said in the beginning, you will save this nation. So I actually encourage you to go ahead and carry out investigative reporting, for that's important.

Sir Paulias is therefore encouraging investigative journalism to take root in this country and in Melanesia as a whole. Other people who publicly support the need for investigative journalism in Melanesia include prominent Papua New Guinea journalists and the head of the South Pacific Center for Communication and Information in Development, Rhonda Eva. Sir Paulias Matane has even suggested areas in which investigative reporters could work on -- if we have that reporting power now -- so that the public is informed of the truth.

MATANE: They tell us time and again that 1995 will be 'flush with cash', that 'we beggars cannot be choosers'. No, we can choose, we can become choosers. And they say all kinds of nice things about the economy -- that the economy is okay. The economy is not okay. We have all the natural resources here, it's rich, but where is all the money going to? This is a very important area for journalists to look into, so that we can be told the truth.

Our leaders, I'm afraid to say, are not telling us the truth. So that's why I say at the beginning, you're the saviours of this nation to tell us the truth. That's my first point.

My second point is: I wonder whether you realise that the second nation with the highest investment in real estate in Eastern Australia -- particularly in Cairns and the Gold Coast - is poor Papua New Guinea. This would be a very good area to investigate, we need to know. It could be that because there's no money here, because a lot of money is going out, it could be that, I don't know. So that $s$ one area you might like to look at.

The other area is that there is a rumour going around the country that some prominent people are now seeking permanent residence outside PNG. I would like to know who these people are if it is true. This is only a rumour but that's important. Why do they want to leave this country? This is our land. Are they running away from something? An interesting topic.

Another interesting topic is someone sold off something here. I don't want to give you the name of whatever business, but a business, to a big company -- a foreign company -- and bought it back with one eighth of the amount that he sold it for. I would like to know whether this is true and if it is true, in business terms. I find it hard to understand why you could sell a business for so much and buy it back for only one seventh of the price that you sell it for. 
However, that is not to say that investigative journalism is perfect. It does face problems, as the Australian long-time investigative journalist, Associate Professor Wendy Bacon, states experiences from her own country.

BACON: For investigative journalism in Australia, defamation is a very big worry. It's a big worry because it's big business and involves a lot of money. Most of the people who sue for defamation are people who have a lot of money and a lot to lose. The average person in Australia, even though often the media is not responsible and is not accountable and there are many things wrong with our media, the average person could never sue -- it will cost far too much.

What happens in Australia, according to Professor Bacon, is that unless journalists have strong media companies, defamation cases are normally settled behind the scenes or out of court. This is because court costs are too high. In recent years, Professor Bacon did a study of 27 investigative stories, and in every single one of those stories, defamation had been a problem to some extent, which sometimes resulted in pressure being put on media companies.

BACON: The problem is not that you don't get to run the story at all, but sometimes the story is so cut, or has to be written in such a way, that actually the story is lost and often becomes very difficult for people to read. But in the cases that have been settled, I want to mention to you that one was the Roger Rogerson case. There were two corrupt New South Wales detectives who did get payouts.

But the other ones have been where people were able to exert enough pressure by withdrawing advertising -- Government advertisements or company advertisements -from the media company. And because media companies depend on advertisements rather than sales revenue to be able to survive, then the threat of withdrawal of adverts is often the best way of all.

The other thing, as I said, is confidential sources. We don't have any [shield] guarantee and in the last few years there's been five contempt of court cases in Australia. Three journalists have gone to jail for not naming sources.

An inquiry in Australia into the rights and obligations of the media recommended that there should be some reform to give journalists rights over the possibility of not naming their confidential sources. At the same time, however, it was also recommended that the media needed to clean up its own act and journalists needed to become more accountable.

When people make complaints they must be followed through. This tends to not happen in Australia and the Pacific Islands region which gives the media a bad name.

BACON: I agree with the Senate that the media should improve its methods of accountability. And then maybe there'll be more public support for some reform, because if we're going to have the right not to name confidential sources we have that right because of the public. We've got that right on behalf of the public to do that so we have to be accountable back to the public. 
On the investigative journalism course at the University of PNG, four senior Papua New Guinea editors and journalists and one Solomon Islands Broadcasting Corporation reporter are the pioneers of the course. One of the journalists taking up this course is Papua New Guineas Dominic Sengi.

DOMINIC SENGI: Something really inspired me to come back to university to this course because I understand in this country there is effectively not enough investigation done by journalists. A lot of issues have gone unreported. This is either because journalists are not grounded or they have not read widely enough to see issues unfolding in the world as they relate to Papua New Guinea.

One requirement -- among many others -- of this course is for participants to present a seminar on a topic being investigated. Mr Sengi was the first course participant to address a seminar organised by SPCenCIID in July . His seminar was on the topic of 'The Gene Hunters Cultural and Social Protection for Indigenous People'.

SENGI: I have specifically chosen this issue of gene hunting because in newspapers last year and also on EM TV, there were snippets of stories on the topic. One little newspaper filler said something to the effect that blood from an indigenous isolated tribe in Papua New Guinea was currently in a queue for application for patenting in the United States.

My concern is, and as a reporter, that these people are predominantly unprotected. They don't know they are beginning to communicate with the rest of the world, they're the last tribe on earth to be discovered and gene hunters regard blood from such a tribe as equivalent to gold.

I set out to read a couple of the latest medical journals on the subject and I was surprised to find that one of the magazines confirmed that genes of the Hagahai have gone to labs in the United States for 'genetic engineering' to determine the types of virus. In my paper, I want to link blood to commerce.

Mr Sengi is a graduate with a bachelor of journalism from UPNG and has worked for several newspaper companies in Papua New Guinea. He is currently attached to the Ministry of Foreign Affairs and Trade in Port Moresby. And that too has been our program for now on Investigative Journalism.

- Walter Nalangu is a Reporter of the Solomon Islands Broadcasting Corporation. This is an edited transcript from a radio documentary prepared by him on a half-day seminar on the theme 'Investigative Journalism in Melanesia Is it Needed?' at UPNG on 27 July 1995. It was broadcast on SIBC's daily current affairs program Wol Blong Iumi on 18 October 1995. 